\title{
Habitat utilization by harpacticoid copepods: a morphometric approach
}

\author{
Susan S. Bell, Keith Walters \& Margaret O. Hall \\ Department of Biology, University of South Florida, Tampa, Florida 33620, USA
}

\begin{abstract}
Examination of harpacticoid copepod morphology was conducted to determine whether morphological resemblance provides a reasonable index of habitat utilization and movement. Discriminant analysis was used to explore the relationship between body form and habitat utilization for copepod species collected from 3 subhabitats within seagrass beds in Tampa Bay, Florida. To examine the accuracy of our procedure the discriminant function derived for Tampa Bay copepods was applied to copepods collected in worldwide studies. Three morphological characteristics - ratio of the length of Pereopod 1 first endopod segment to the remaining endopod segments, area of the cephalosome, and length of the first antennule - significantly contributed to variation in habitat utilization by identifiable groups. Habitat utilization suggested from the literature corresponded well to that predicted by the discriminant function derived for Tampa Bay harpacticoids. Our findings will be useful to suggest which copepods should (1) be associated with vegetation (2) display active migration and ( 3 ) be linked to sediment processes.
\end{abstract}

\section{INTRODUCTION}

Extant families of harpacticoid copepods may have evolved from an epibenthic ancestor to exploit not only sediment but also phytal and planktonic habitats (Por 1984). A wide range of harpacticoid body forms has accompanied the exploitation of these diverse habitats. While most sediment harpacticoids are vermiform or torpedo shaped, phytal or epibenthic species display a host of body shapes including lateral and dorsal-ventral compression of the body, extremely rounded or broadened cephalosomes and larger overall size (Noodt 1971). The ecological literature on harpacticoid copepods has traditionally focused upon studies of sediment-dwelling species (see Coull \& Bell 1979, Hicks \& Coull 1983 for reviews). Available information concerning copepod species living phytally, epibenthically or in the water column suggests that these morphologically diverse forms also have ecological traits which differ from those of sediment-dwelling species (Marcotte 1983, Hicks 1985).

Studies on the distribution and abundance of seagrass meiofauna in Tampa Bay, Florida, have identified 3 habitats utilized by harpacticoid copepods (Bell et al. 1984). Harpacticoids have been collected from seagrass blade surfaces and within sediments. In addition, some copepods sometimes recovered in sedi- ment cores migrate from the sediments into the overlying water column. Thus differences in habitat usage by the wide variety of harpacticoid copepods in Tampa Bay seagrass systems may be related to behavioral traits. Accordingly, species which are found living on seagrass blades, in the sediments, or moving into the water column from either blades or sediments, should exhibit variation on one or more morphological characteristics given that each of these habitats requires specialized features. We ask here whether specific habitat utilization is related to, or can be predicted by, morphological characteristics of harpacticoid copepods.

\section{METHODS AND MATERIALS}

Discriminant analysis was used to examine the relationship between copepod morphology and habitat utilization (Norusis 1985). The SPSSX (Nie 1983) package of statistical procedures was used for all analyses. First, copepods from Tampa Bay seagrass beds were assigned a priori to one of 3 groups (phytal, water column or migrator, sediment) based upon their distribution in the field. Twenty of the most common copepod species representing 13 families from collections in seagrass habitats from Tampa Bay, Florida, 
(Table 1) were used in this first analysis. We assumed that collection of copepods from different subhabitats of the seagrass bed reflected differences in habitat utilization. Some species were collected from more than one habitat but were assigned to the category where they were relatively most abundant. Body measurements for each species were made on females and included length of antennule $\left(A_{1} L\right)$, length and width of cephalosome (CL and CW, respectively), length of urosome (UL), length of caudal rami including setae (CRL) and length of Pereopod $1\left(P_{1}\right)$ endopod first, second, and third (if present) segments (Fig. 1). Length and width of cephalosome were multiplied to obtain cephalosome area (CA). The ratio of length of $P_{1}$ Endopod 1 to length of $P_{1}$ Endopod 2 plus Endopod 3 $\left(P_{1} R\right)$ was calculated. The particular combination of measurements $A_{1} L, C A, P_{1} R, U L$, and $C R L$ was chosen because these specialized morphological characteristics may be related to habitat utilization (Noodt 1971) and provided the best set of non-correlated morphological traits for discriminant analyses, the latter a desir- able feature of characters used in such analyses. Measurement of cephalosome length and width and metasome length were considered in preliminary analyses. Cross-correlations between these and the other measurements were often above 0.9, thus the number of independent morphological variables was reduced to those given above. Measurements were made on either mounts of copepods with an ocular micrometer and compound microscope or from literature descriptions, mostly Lang (1948), using vernier calipers. All measurements, except those of $\mathrm{P}_{1}$, were converted to $\mathrm{mm}$ using information on the largest size of females. Values for $P_{1}$ endopod lengths were expressed as ratios of measurement units because not all descriptions of pereopods contained scale dimensions (e.g. Lang 1948).

The 5 morphological variables for the 20 species from Tampa Bay seagrass habitats constituted the independent variables which were used to discriminate between the habitat groups. Variables were log transformed to meet assumptions of normality and

Table 1. Species and families of copepods used in discriminant analyses from (A) Tampa Bay seagrass beds and (B) literature reports. A priori classification (P: phytal, $\mathrm{M}$ : migrator, S: sediment dweller) is noted in parentheses

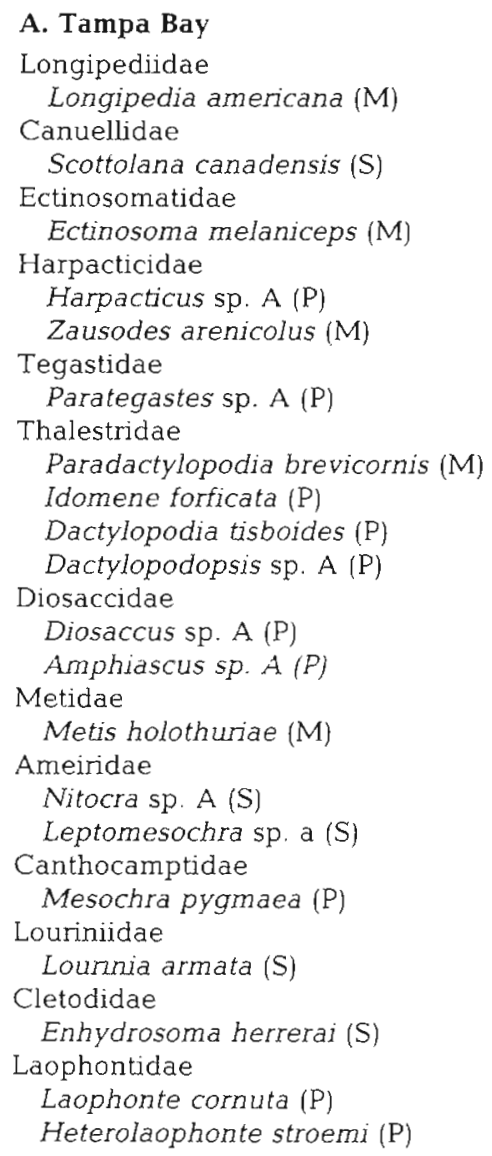

A. Tampa Bay

Longipediidae

Longipedia americana (M)

Canuellidae

Scottolana canadensis (S)

Ectinosomatidae

Ectinosoma melaniceps (M)

Harpacticidae

Harpacticus sp. A (P)

Zausodes arenicolus (M)

Tegastidae

Parategastes sp. A (P)

Thalestridae

Paradactylopodia brevicornis (M)

Idomene forficata $(\mathrm{P})$

Dactylopodia tisboides $(\mathrm{P})$

Dactylopodopsis sp. A (P)

Diosaccidae

Diosaccus sp. A (P)

Amphiascus sp. A (P)

Metidae

Metis holothuriae (M)

Ameiridae

Nitocra sp. A (S)

Leptomesochra sp. a (S)

Canthocamptidae

Mesochra pygmaea (P)

Louriniidae

Lounnia armata (S)

Cletodidae

Enhydrosoma herrerai (S)

Laophontidae

Laophonte cornuta (P)

Heterolaophonte stroemi $(\mathrm{P})$

\section{B. Literature}

Harpacticidae

Harpacticus chelifer $(P)$

Zaus spinatus $(\mathrm{P})$

Tachidiidae

Microarthridion littorale (S)

Tisbidae

Tisbe furcata $(\mathrm{P})$

Sacodiscus Littoralis (P)

Peltidiidae

Neopeltopsis pectinipes (P)

Eupelte beckleyae (P)

Thalestridae

Dactylopodia vulgaris $(\mathrm{P})$

Thalestris longimana (P)

Parathalestris harpactoides (P)

Phyllothalestris mysis (P)

Parathalestris clausi (P)

Diosaccidae

Amphiascus minutus (P)

Amonardia normani $(\mathrm{P})$

Ameiridae

Ameira minuta $(\mathrm{P})$

Tetragonicepsidae

Phyllopodopsyllus bradya (S)

Canthocamptidae

Orthopsyllus linearis $(\mathrm{P})$

Cletodidae

Huntemannia jadensis (S)

Nannopus palustris (S)

Enhydrosoma propinquum (S)

Cylindropsyllidae

Stenocaris minuta (S) 


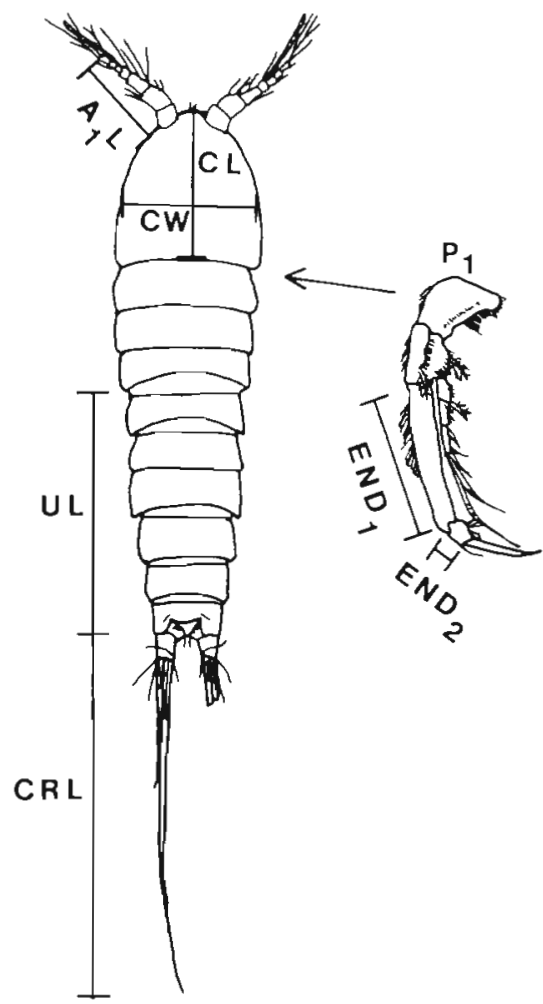

Fig. 1. Diagrammatic illustration of morphological measurements made on harpacticoid copepods used in discriminant analyses. $A_{1} L$ : antennule length; $C W$ : cephalosome width: CL: cephalosome length; UL: urosome length; CRL: caudal rami length; $P_{1}$ : Pereopod $1 ; E_{N} D_{1}$; endopod first segment length; $\mathrm{END}_{2}$ : Endopod 1 second segment length

assure a non-singular covariance matrix (Williams 1983). Initially a stepwise procedure was run to identify variables which provided the best separation between groups (i.e. phytal vs water column vs sediment) such that between-group variability was greater than within-group variability. A forward entry of variables based upon the minimization of Wilk's Lambda was employed. Next, a discriminant function was generated for the 20 species from Tampa Bay using variables identified as important in the stepwise procedures. The discriminant function provided coefficients for each variable which could then be used to generate a discriminant score for each species. The proportion of cases in each a priori category (see Table 1) was used as an estimate of the prior probability'. By using the discriminant function, each species could be assigned to one of the 3 groups (phytal, water column, sediment) and then compared to the original grouping based on our arbitrary assessment of habitat utilization.

To examine the accuracy of our classification of copepods from Tampa Bay seagrass sites, we applied the same discriminant analyses to copepods selected from the literature for whom group membership or habitat affinity was reported. Groupings predicted by our discriminant function were then compared to the reported habitat utilization. A total of 21 copepods, including species from literature on fauna inhabiting seagrass beds (Decho et al. 1985), living associated with plants (Hicks 1976, 1977, 1982) or moving from sediments (Eckman 1983, Chandler \& Fleeger 1983, Palmer \& Gust 1985) (Table 1) were used. Our methods for collecting measurements for the literature species followed that of the Tampa Bay fauna. A priori category assignment (i.e. phytal vs water, column vs sediment) for literature copepods was extracted from the data provided in the studies. Discriminant scores for literature species were calculated using the functions generated for copepods in Tampa Bay seagrass beds.

\section{RESULTS}

Three morphological characteristics of Tampa Bay copepods were identified as significantly contributing to the variation between habitat utilization by groups (Table 2). $P_{1} R$ was the first variable to enter the model

Table 2. Summary table of (A) stepwise procedure using minimization of Wilk's lambda and (B) unstandardized canonical discriminant coefficients. $P_{1} R$ : (length $P_{1}$ Endopod 1) / (length $P_{1}$ Endopod $\left.2+3\right)_{i} C A_{\text {: }}$ cephalosome area; $A_{1} L_{\text {: }}$ First antennule length

\begin{tabular}{|cccc|}
\hline $\begin{array}{c}\text { A. Stepwise procedure } \\
\text { Step }\end{array}$ & $\begin{array}{c}\text { Variable } \\
\text { entered }\end{array}$ & $\begin{array}{c}\text { Wik's } \\
\text { lambda }\end{array}$ & $\begin{array}{c}\text { Significance } \\
\text { (p value) }\end{array}$ \\
\hline 1 & $\mathrm{P}_{1} \mathrm{R}$ & 0.604 & 0.013 \\
2 & $\mathrm{CA}$ & 0.536 & 0.036 \\
3 & $\mathrm{~A}_{1} \mathrm{~L}$ & 0.415 & 0.029 \\
B. Discriminant coefficients & & \\
\multicolumn{5}{r}{ Function 1 } & Function 2 & \\
CA & -1.17 & -1.8 & \\
$\mathrm{~A}_{1} \mathrm{~L}$ & -1.10 & 5.7 & \\
$\mathrm{P}_{1} \mathrm{R}$ & 2.72 & 0.78 \\
Constant & 2.64 & -3.0 \\
\hline
\end{tabular}

significantly (Norusis 1985). CA and $A_{1} L$ were the second and third variables to enter the model, respectively (Table 2A).

Two discriminant functions were generated using the 3 variables identified from above (Table 2B). The first function accounted for $73.3 \%$ and the second function accounted for $26.7 \%$ of the between-group variability, respectively. The coefficients for $\mathrm{CA}_{1} \mathrm{~A}_{1} \mathrm{~L}$ and $P_{1} R$ used in Functions 1 and 2 to calculate discriminant scores are presented in Table 2 . We a priori 
correctly classified $75 \%$ of Tampa Bay seagrass species into habitat groups based upon the calculated functions. Five species were 'misclassified' by our quantitative method (i.e. had a higher probability of fitting into another category) and their classifications according to the discriminant function are presented in Table $3 \mathrm{~A}$.

Table 3. Species misclassified by discriminant functions from Tampa Bay data set (A) and literature cases (B). A prior classification is from Table 1 and discriminant classification is based upon discriminant scores. Abbreviations as in Table 1

\begin{tabular}{|lll|}
\hline \multicolumn{1}{|c}{ Species } & $\begin{array}{c}\text { A prioni } \\
\text { classification }\end{array}$ & $\begin{array}{c}\text { Discriminant } \\
\text { classification }\end{array}$ \\
\hline A. Tampa Bay & & \\
Mesochra pygmaea & $\mathrm{P}$ & $\mathrm{M}$ \\
Zausodes arenicolus & $\mathrm{M}$ & $\mathrm{P}$ \\
Paradactylopodia brevicornis & $\mathrm{M}$ & $\mathrm{P}$ \\
Ectinosoma melaniceps & $\mathrm{M}$ & $\mathrm{S}$ \\
Lourinia armata & $\mathrm{S}$ & $\mathrm{M}$ \\
& & \\
B. Literature & & $\mathrm{S}$ \\
Tisbe furcata & $\mathrm{P}$ & $\mathrm{M}$ \\
Amonardia normani & $\mathrm{P}$ & $\mathrm{P}$ \\
Huntemannia jadensis & $\mathrm{S}$ & $\mathrm{P}$ \\
Phyllopodopsyllus bradya & $\mathrm{S}$ & \\
\hline
\end{tabular}

Applying the discriminant function derived from Tampa Bay copepods to harpacticoids from the literature resulted in good correspondence between habitat utilization as defined in the studies and that identified from morphological traits and our discriminant function. Only phytal or sediment-dwelling copepods were obtained from the literature. Four species were categorised into a group by the discriminant scores that did not match the category assigned previously in the literature. The copepods misclassified from the literature are presented in Table $3 \mathrm{~B}$ along with their calculated group assignment. A combined plot of the discriminant scores and group centroids for the 2 functions for each species from both the Tampa Bay and literature data sets is presented in Fig. 2.

\section{DISCUSSION}

Overall, the discriminant analysis provided good separation of copepods into groups based upon 3 morphological traits: the ratio of the length of $\mathrm{P}_{1}$ Endopod 1 to $P_{1}$ Endopod 2 plus $3\left(P_{1} R\right)$, the length of the antennule $\left(A_{1} L\right)$, and the area of the cephalosome (CA) (Tables 2 \& 3, Fig. 2). Such multivariate analyses more precisely summarize the qualitative observations that copepods living in different habitats have different forms (Hicks \& Coull 1983) and illustrate that morphological resemblance provides a reasonable index to habitat utilization or movement. Because many of the species or genera used in our analyses are often abundant or represented in other studies on harpacticoid copepods (Por 1964, Kito 1977, Coull et al. 1979, Pallares 1979), we would expect our results to provide

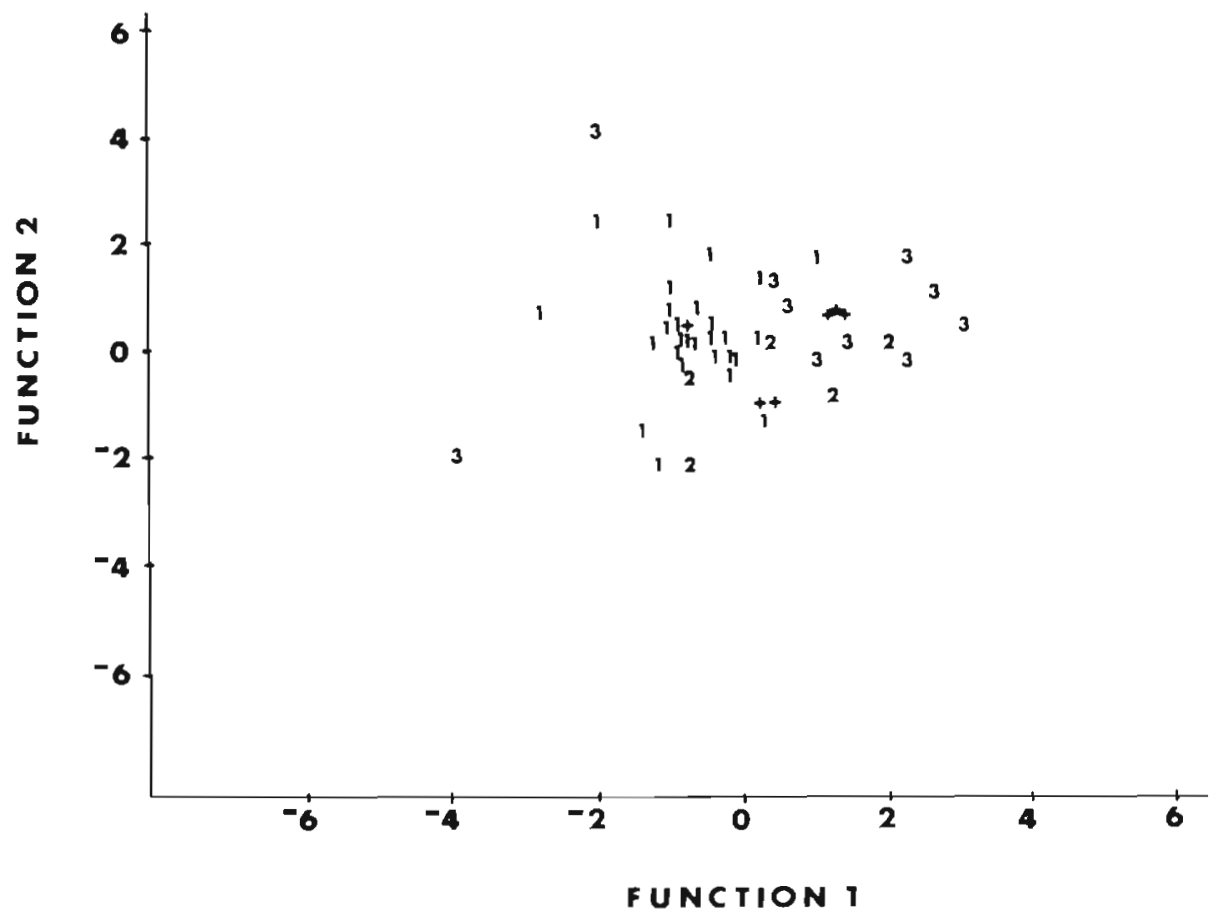

Fig. 2. Plot of species by group for discriminant Functions 1 and 2. 1: Phytal; 2: Migrator; 3: Sediment. Group centroids for phytal ( + ), migrators $(+t)$ and sediment $(+++)$ forms are also provided 
insight into the habitat utilization of many world-wide copepod taxa.

The best morphological characteristic upon which to segregate species was $P_{1} R$, although both $C A$ and $A_{1} L$ were also important. The $\mathrm{P}_{1}$ character state deserves particular attention. As has been repeatedly noticed for copepods, those that are phytal associates generally possess a modified $P_{1}$ which is strongly prehensile $\left(P_{1}\right.$ Endopod $1>\mathrm{P}_{1}$ Endopod 2 plus 3), modified presumably for grasping the substrate. Our results confirm that phytal forms have a strongly prehensile $P_{1}$ and migrators have moderately prehensile $P_{1}$ endopods while sediment forms rarely have a first segment exceeding the length of the remaining segments. The exact relation between $A_{1} L$ and $C A$ and copepod utilization of habitat is still unknown, although Marcotte (1983) reports that an enlarged cephalosome, characteristic of migrators and phytal forms, serves as an aid to swimming.

Some of the cases of copepod misclassification from the literature can be explained by inspection of the $P_{1}$ arrangement. Specifically, while Huntemannia jadensis has been reported as a sediment form (Eckman 1983), it was assigned to the phytal category by the discriminant scores. This is a result of the $\mathrm{P}_{1}$ endopod having only 1 segment which when expressed as a ratio, makes it appear infinitely 'prehensile'. Proportionately, the $\mathrm{P}_{1}$ endopod is comparable to that of other burrowing, sediment dwellers. Likewise, Tisbe furcata has a $\mathrm{P}_{1}$ endopod that is elongated for both the first and second segment. Such a relation of approximately equal segment sizes within the $P_{1}$ is typical of sediment-dwelling forms and is the reason $T$. furcata is classified as a sediment species when it clearly utilizes phytal or water column habitats. Direct measurement of the relative length of each segment of the $P_{1}$ endopod, if available, could avoid these problems.

Amonardia normani was the only species from the literature that was classified as a migrator based upon morphology. A. normani has been reported from algae, and Castel \& Lasserre (1977) reported the species from both sediment and submerged plants in lagoons. No extensive distributional data are available on Phyllopodysyllus bradya to evaluate its classification.

Four of the 5 species misclassified in the Tampa Bay data set represent those species which were often collected in more than one habitat. For example, Mesochra pygmaea was often captured in the water column although it was periodically very abundant on seagrass blades. Paradactylopodia brevicornis was common on plant structure as well as in the water column, but also dominated sediments at other sites within Tampa Bay seasonally (e.g. Kern \& Bell 1984). Furthermore, Lourinia armata was classified as a sediment dweller in Tampa Bay but designated a migrator by its discriminant score. Although this species does not inhabit seagrasses it has been reported in high abundances living epibenthically on scallop shells (K. Sherman pers comm.), and coralline algae (Hicks 1977), presumably among the entrapped sediments, and occasionally enters water column traps in Tampa Bay (Walters \& Bell 1986). Ectinosoma melaniceps is clearly itinerant, being found in phytal, sediment and water column samples. These findings suggest that there is not a strict separation among habitats by some species i.e. some migrators divide their time between a substratum and the water column. The results for Zausodes arenicolus are enigmatic and not easily explained since this species with 'phytal-like' morphology is abundant in sediments (Kern et al. 1984) and is a dominant migrator (Service 1986). In this last case, behavior/habitat utilization do not follow the same relation as other copepods.

Interestingly, only one species from the literature was placed into the category of migrator based upon morphology. No species from the literature was designated a priori as a migrator in published studies. In contrast, at least 5 species were collected in the water column in Tampa Bay. This migratory group of species was morphologically discernible. Thus, the noted active movement of the Tampa Bay forms in contrast to the passive resuspension suggested for some sediment forms (e.g. Eckman 1983, Palmer \& Gust 1985) is reaffirmed by morphological evidence. The consistent agreement of the discriminant analysis to previous literature descriptions (above) and the world-wide distribution of copepod species similar to those investigated here suggests that our findings may be useful to predict which copepods should (1) be associated with vegetation, (2) display active migration and/or (3) live among sediments and be closely linked to flow regimes and sediment entrainment. Because interstitial copepods were not present in the original data set we have not included them in our model, however they would serve as an additional test for the discrimination power of the morphological traits used in our model.

Studies on harpacticoid copepod morphology are common, with some addressing the interesting question of morphological variation within a species (e.g. Coull \& Fleeger 1977) or family (e.g. Montagna 1982). Additional morphological investigations of copepod functional groups comprising many species have also been reported (Marcotte 1977. Thistle 1982) but categories have not been quantitatively derived. Our approach here has differed in that we chose to examine a broad range of copepod species and by using quantitative analyses on a combination of traits, derived a predictive model. 
Acknowledgements. The work was supported in part by grants from the National Science Foundation from the Biological Oceanography Program (OCE 80017261A) and International Programs (84-NZ-02) (S. S. Bell, Principal Investigator). We thank G. R. F. Hicks and anonymous reviewers for their insightful comments.

\section{LITERATURE CITED}

Bell, S. S., Walters, K. Kern, J. C. (1984). Meiofauna from seagrass habitats: a review and prospectus for future research. Estuaries 7: 331-338

Castel, J., Lasserre, P. (1977). Colonisation et distribution spatiale des copepodes dans les lagunes semi-artificielles. In: Keegan, B. F., Cedigh, P. O., Boaden, P. J. S. (ed.) Biology of benthic organisms. Pergamon Press, New York, p. $129-146$

Chandler, T. G., Fleeger, J. W. (1983). Meiofaunal colonization of azoic sediment in Louisiana: mechanisms of dispersal. J. exp. mar. Biol. Ecol. 69: 175-188

Coull, B. C., Bell, S. S. (1979). Perspectives of Maine meiofauna ecology. In: Livingston, R. J. (ed.) Ecological processes in coastal and marine systems. Plenum Press, New York, p. $189-216$

Coull, B. C., Bell, S. S., Savory, A. M., Dudley, B. W. (1979). Zonation of meiobenthic copepods in a southeastern United States salt marsh. Estuar. coast. mar. Sci. 9: $181-188$

Coull, B. C., Fleeger, J. W. (1977). A new species of Pseudostenhelia, and morphological variation in Nannopus palustris (Copepoda, Harpacticoida). Trans. Am. microsc. Soc. 96: 332-340

Decho, A. W., Hummon, W. D., Fleeger, J. W. (1985) Meiofauna-sediment interactions around subtropical seagrass sediments using factor analysis. J. mar. Res. 43: $237-255$

Eckman, J. E. (1983). Hydrodynamic processes affecting benthic recruitment. Limnol. Oceanogr 28: 241-257

Hicks, G. R. F. (1976). Neopeltopsis pectinipes, a new genus and species of seaweed-dwelling copepod (Harpacticoida: Peltidiidae) from Wellington, New Zealand. N. Z Jl mar. Freshwat. Res. 10: 363-370

Hicks, G. R. F. (1977). Species associations and seasonal population densities of marine phytal harpacticoid copepods from Cook Strait. N. Z. Jl mar. Freshwat. Res. 11: 621-643

Hicks, G. R. F. (1982). Porcellidiidae and Peltidiidae (Copepoda: Harpacticoida) from the marine algae of St. Croix Isiand, Algoa Bay, South Africa. J. Linn. Soc. 75: 49-90

Hicks, G. R. F. (1985). Meiofauna associated with rocky shore algae. In: Moore, P. G., Sneed, R. (ed.) The ecology of rocky coasts. Hodder and Stoughton, London, p. 36-56
Hicks, G. R. F, Coull, B. C. (1983). The ecology of marine meiobenthic harpacticoid copepods. Oceanogr. mar. Biol A. Rev. 21: 67-175

Kern, J. C., Bell, S. S. (1984). Short-term temporal variation in population structure of two harpacticoid copepods, Zausodes arenicolus Wilson and Paradactylopodia brevicornjs (Claus). Mar. Biol. 84: 53-63

Kern, J. C., Edward, N. A., Bell. S. S. (1984). Precocious clasping of early copepodite stages: a common occurrence in Zausodes arenicolus Wilson (Copepoda: Harpacticoida). J. Crust. Biol. 4: 261-265

Kito, K. (1977). Phytal animals in the Sargassum confusum region in Oshoro Bay, Hokkaido: phenology of harpacticoid copepods. J. Fac. Sci. Hokkaido Univ. VI Zool. 20 $691-696$

Lang, K. (1948). Monographie der Harpacticiden. O. Koeltz Science, Königstein

Marcotte, B. M. (1977). The ecology of meiobenthic harpacticoids (Crustacea: Copepoda) in West Lawrenceton, Nova Scotia. Ph. D. dissertation, Dalhousie University, Halifax

Marcotte, B. M. (1983). The imperatives of copepod diversity: perception, cognition, competition and predation. In: Schram, F. R. (ed.) Crustacean phylogeny. A. A. Balkema Publishers, Rotterdam, p. 47-72

Montagna, P. A. (1982). Morphological adaptation in the deep-sea benthic harpacticoid copepod family Cerviniidae. Crustaceana 42: 37-43

Nie, N. H. (1983). SPSSX user guide. McGraw-Hill, New York

Noodt, W. (1971). Ecology of the Copepoda. In: Hulings, N. C. (ed.) Proceedings of the first international conference on meiofauna. Smithson. Contr. Zool. 75: 97-102

Norusis, M. J. (1985). SPSSX advanced statistics guide McGraw-Hill, New York

Pallares, R. E. (1979). Copepods harpacticoides marinos de Tierra Del Fuego (Argentina), Isla de Los Estados III Contribución Científica \#142 del Centro de Investigación de Biología Marina

Palmer, M. A., Gust, G. (1985). Dispersal of meiofauna in a turbulent tidal creek. J. mar. Res. 43: 174-210

Por, F. D. (1964). A study of the Levantine and Pontic Harpacticoida (Crustacea, Copepoda). Zool. Verh., Leiden 64 $1-128$

Por, F. D. (1984). Canuellidae Lang (Harpacticoida, Polyarthra) and the ancestry of the Copepoda. Crustaceana 43 : $1-24$

Service, S. K. (1986). Manipulative studies of the effects of harpacticoid copepod density on dispersal. M. S. thesis, Univ, of South Florida, Tampa

Thistle, D. (1982). Aspects of the natural history of harpacticoid copepods of San Diego Trough. Biol. Oceanogr 1 $225-238$

Walters, K., Bell, S. S. (1986). Diel patterns of active vertical migration in seagrass meiofauna. Mar. Ecol. Prog. Ser. 34: 95-103

Williams, B. K. (1983). Some observations on the use of discriminant analysis in ecology. Ecology 64: 1283-1291 